\title{
Analisis Pelaksanaan Kurikulum 2013 dalam Proses Pembelajaran SD Inpres 135 Hasik Jaya Kabupaten Sorsel
}

\author{
Adrianus Tambing Bontong ${ }^{1}$, Muhammad Faizin ${ }^{2} \&$ Syams \\ Kusumaningrum $^{3}$
}

Prodi PGSD, Universitas Pendidikan Muhammadiyah Sorong, Indonesia

$\bowtie$ E-mail: Adrianusbontong@gmail.com

\begin{abstract}
Abstrak
Penelitian ini bertujuan untuk mengetahui pelaksanaan kurikulum 2013 dalam proses pembelajaran dan mendiskripsikan pelaksanaan kurikulum 2013 dalam proses pembelajaran di SD Inpres 135 Hasik Jaya Kabupaten Sorong Selatan. Penelitian ini menggunakan jenis penelitian kualitatif. Subjek dalam penelitian ini adalah kepala sekolah dan satu guru kelas IV. Instrumen yang digunakan adalah observasi dan wawancara. Teknik analisis data dalam penelitian ini menggunakan teknik analisis kualitatif yaitu Reduksi data, penyajian data, dan penarikan kesimpulan. Hasil penelitian ini adalah kegiatan pembelajaran mulai dari perencanaan, pelaksanaan, dan penilaian dibuat guru sudah sesuai dengan komponen-komponen K13. Pelaksanaan K13terdapat beberapa kendala; 1) kendala yang guru alami adalah kekurangan media pembelajaran dan 2) guru mengalami kebingungan dalam melaksanakan proses penilaian, karena pada saat pembelajaran dilaksanakan dengan pendekatan tematik, namun dalam tahap penilaian guru harus melakukan penilaian setiap muatan pelajaran. Kesimpulan yang diperoleh dalam penelitian ini bahwa pelaksanaan kurikulum 2013 dalam proses pembelajaran SD Inpres 135 Hasik Jaya kabupaten Sorong sudah diterapkan, namun masih terdapat hambatan dalam tahap penilaian ketika guru bingung bagaimana melakukan proses penilaian.
\end{abstract}

Kata Kunci: Analisis; Kurikulum 2013; Proses pembelajaran.

\begin{abstract}
This study aims to determine the implementation of the 2013 curriculum in the learning process and describe the implementation of the 2013 curriculum in the learning process at SD Inpres 135 Hasik Jaya, Kabupaten Sorong Selatan. This study uses a qualitative research type. The subjects in this study were the principal and one fourth-grade teacher. The instruments used are observation and interviews. Data analysis techniques in this study used qualitative analysis techniques, namely data reduction, data display, and verification. The results of this study are learning activities ranging from planning, implementation, and assessment made by the teacher are in accordance with the K13 components. There are several obstacles that teachers face during the implementation stage; 1) teachers face a lack of learning media, and 2) teachers face confusion during the assessment process because learning is done using a thematic approach, but during the assessment stage, the teacher must evaluate each lesson content. The conclusion obtained in this study is that the implementation of the 2013 curriculum in the learning process of SD Inpres 135 Hasik Jaya, Sorong district has been implemented, but there are still obstacles in the assessment stage when teachers are confused about how to carry out the assessment process.
\end{abstract}

Keywords: Analysis; 2013 Curriculum; Learning Proces 


\section{PENDAHULUAN}

Kurikulum adalah salah satu komponen yang penting dan utama dalam pendidikan. Kurikulum menentukan arah pencapaian tujuan pendidikan nasional Indonesia. Kurikulum merupakan bagian penting dari sekolah dan hal ini menjadi komponen penting dalam proses belajar mengajar di sekolah. Pelaksanaan pembelajaran kurikulum 2013 (K13) untuk tingkat SD menerapkan pembelajaran tematik.

Penerapan K13 belum merata pada sekolah dasar di Indonesia. Pemerintah menentukan beberapa sekolah dasar yang menjadi sekolah sasaran dalam uji coba penerapan K13. Tidak menutup kemungkinan bagi sekolah non sasaran untuk menerapkan K13 secara mandiri. Selain itu, guru juga dituntut untuk lebih menekankan pada proses, bukan pada hasil. Tujuan dari hal tersebut adalah agar peserta didik sebagai sasaran utama perubahan kurikulum ini diharapkan akan mampu menjadi pribadi yang berkarakter.

Pada kenyataannya pelaksanaan pembelajaran K13 belum berjalan sesuai dengan apa yang diharapkan oleh pemerintah. Berbagai kendala seperti guru yang kesulitan dalam pembuatan rencana pembelajaran sampai kesulitan melakukan peniliaan dalam K13 menjadi kendala utama dalam penerapan kurikulum ini. Sebuah studi yang dilakukan oleh Warami (2014) tentang "Implementasi Kurikulum 2013 di Era Otsus Papua" menyatakan bahwa peserta didik yang mengikuti pendidikan masa kini di Tanah Papua akan mengalami fase transisi dengan menggunakan apa yang diperolehnya dari pendidikan diharapkan dapat dikembangkan dari warisan budaya dan kehidupan masa kini sebagai langkah awal dalam menyelesaikan pendidikan formalnya. K13 dirancang untuk memberikan pengalaman belajar seluas-luasnya bagi peserta didik untuk mengembangkan sikap, keterampilan dan pengetahuan yang diperlukan untuk membangun kemampuan tersebut, namun sejatinya hasil dari pengalaman belajar peserta didik di Tanah Papua belum tampak secara signifikan menggambarkan hasil belajar manusia dengan kualitas yang diinginkan.

Berdasarkan permasalahan diatas, dilakukan kajian pelaksanaan K13 di SD Inpres 135 Hasik Jaya sebagai salah satu sekolah yang sudah menerapkan K13 di Kabupaten Sorong Selatan. Kajian dilakukan untuk mengetahui apakah K13 sudah terlaksana dengan baik mengingat lokasi sekolah yang jauh dari perkotaan (3T). Selain itu, kajian ini diharapkan dapat mengetahui kendala apa saja yang dialami pihak sekolah dalam melaksanakan K13.

K13 merupakan sebuah kurikulum yang mengutamakan pemahaman, skill, dan pendidikan berkarakter, peserta didik dituntut untuk paham atas materi, aktif dalam berdiskusi dan presentasi serta memiliki sopan santun disiplin yang tinggi. Kurikulum ini menggantikan KTSP yang diterapkan sejak 2006 lalu. Dalam K13 mata pelajaran wajib diikuti oleh seluruh peserta didik di satu satuan pendidikan pada setiap satuan atau jenjang pendidikan.

Karakter khas K13 adalah: (1). Isi atau konten kurikulum yaitu kompetensi dinyatakan dalam bentuk Kompetensi Inti (KI) satuan pendidikan dan kelas, dirinci lebih lanjut dalam Kompetensi Dasar (KD) mata pelajaran. (2). KI merupakan gambaran secara kategorial mengenai kompetensi dalam aspek sikap, pengetahuan, dan keterampilan (kognitif dan psikomotor) yang harus dipelajari peserta didik untuk suatu jenjang sekolah, kelas dan mata pelajaran. (3). KD merupakan kompetensi yang 
dipelajari peserta didik untuk suatu tema untuk SD, dan untuk mata pelajaran di kelas tertentu untuk SMP, SMA/SMK. (4). KI dan KD dijenjang pendidikan menengah diutamakan pada ranah sikap sedangkan pada jenjang pendidikan menengah berimbang antara sikap dan kemampuan intelektual (kemampuan kognitif tinggi). (5). KI menjadi unsur organisatoris (organizing elements) KD yaitu semua KD dan proses pembelajaran dikembangkan untuk mencapai kompetensi dalam KI. (6). KD yang dikembangkan didasarkan pada prinsip akumulatif saling memperkuat (reinforced) dan memperkaya (enriched) antar mata pelajaran dan jenjang pendidikan diikat oleh kompetensi inti. (7). Silabus dikembangkan sebagai rancangan belajar untuk satu tema (SD). Dalam silabus tercantum seluruh KD untuk tema atau mata pelajaran di kelas tersebut. (8). Rencana Pelaksanaan Pembelajaran dikembangkan dari setiap KD yang untuk mata pelajaran dan kelas tersebut (Shobirin, 2016).

Perencanaan pembelajaran dibuat dalam bentuk Silabus dan RPP yang mengacu pada Standar Isi. Perencanaan pembelajaran meliputi penyusunan rencana pelaksanaan pembelajaran dan penyiapan media dan sumber belajar, perangkat penilaian pembelajaran, dan skenario pembelajaran. Penyusunan Silabus dan RPP disesuaikan dengan pendekatan pembelajaran yang digunakan.

Pembelajaran K13 diimplementasikan dalam penyusunan RPP dan dikembangkan dari silabus untuk mengarahkan kegiatan pembelajaran peserta didik dalam upaya mencapai KD. Setiap pendidik pada satuan pendidikan berkewajiban menyusun RPP secara lengkap dan sistematis agar pembelajaran berlangsung secara interaktif, inspiratif, menyenangkan, menantang, efisien, memotivasi peserta didik untuk berpartisipasi aktif, serta memberikan ruang yang cukup bagi prakarsa, kreativitas, dan kemandirian sesuai dengan bakat, minat, dan perkembangan fisik serta psikologis peserta didik. RPP disusun berdasarkan KD atau subtema yang dilaksanakan dalam satu kali pertemuan atau lebih.

Penilaian pembelajaran merupakan serangkaian kegiatan untuk memperoleh, menganalisis, dan menafsirkan data tentang proses dan hasil belajar peserta didik yang dilakukan secara sistematis dan berkesinambungan, sehingga menjadi informasi yang bermakna dalam pengambilan keputusan.

\section{METODE PENELITIAN}

Penelitian ini menggunakan jenis penelitian kualitatif dan pendekatan studi kasus. Sumber data diperoleh dari data primer dan sekunder. Data primer diperoleh melalui wawancara informan. Informan tersebut terdiri dari kepala sekolah dan satu orang guru kelas IV SD Inpres 135 Hasik Jaya di Kabupaten Sorong Selatan. Data sekunder diperoleh dengan melakukan observasi terhadap dokumen (perangkat pembelajaran) yang telah dibuat di sekolah. Penelitian dilaksanakan dari tanggal 26 Maret - 26 April 2021.

Observasi yang digunakan adalah observasi terstruktur dan diisi oleh peneliti sebagai observer. Lembar pengamatan atau observasi ini menggunakan metode checklist dengan memberikan tanda tally $(\sqrt{ })$ setiap pemunculan gejala yang dimaksud, dalam lembar observasi dan kemudian dilanjutkan dengan dokumentasi. Wawancara yang dilakukan memakai wawancara terstruktur, dimana bahan-bahan untuk wawancara sudah disiapkan terstruktur dan menggunakan pedoman wawancara (interview guide) yang 
telah disusun sedemikian rupa.

Untuk memeriksa validitas data menggunakan teknik triangulasi sumber. Teknik jenis ini digunakan untuk membandingkan hasil wawancara yang diperoleh dari masing-masing sumber atau informan, serta untuk mengecek kebenaran informasi yang didapatkan. Teknik analisis data dalam penelitian ini menggunakan teknik analisis kualitatif. Menurut Miles and Huberman (Sugiyono, 2018) aktivitas dalam analisis data kualitatif dilakukan secara interaktif dan berlangsung secara terus menerus sampai tuntas, sehingga datanya sudah jenuh. Aktivitas dalam analisis data, yaitu reduksi data, penyajian data, dan penarikan kesimpulan.

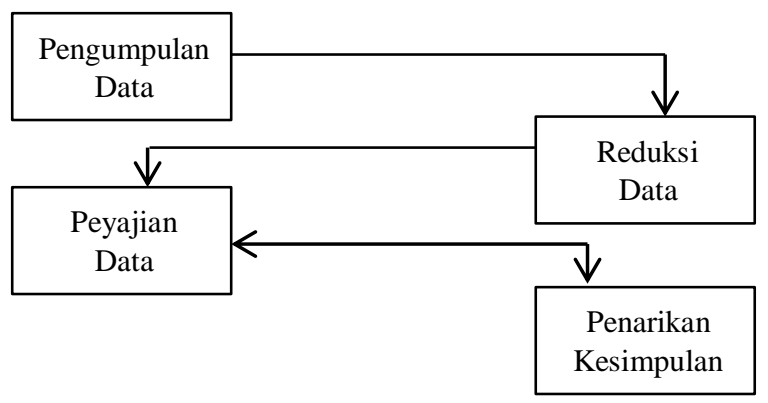

Gambar 1. Skema Model Analisis Interaktif

Pada tahap reduksi data, dilakukan pemilihan tentang relevan tidaknya antara data dengan tujuan penelitian. Data yang diperoleh dari penelitian yang beragam dengan memadukan beberapa teknik. Informasi dari lapangan sebagai bahan mentah yang kemudian diringkas, disusun lebih sistematis, serta ditonjolkan pokokpokok yang penting sehingga lebih mudah dikendalikan. Setelah tahap mereduksi data selesai dilakukan,

Pada tahap penyaian data, klasifikasi dan penyajian data dilakukan sesuai dengan pokok permasalahan yang diawali dengan pengkodean pada setiap sub pokok permasalahan. Untuk memudahkan memperoleh kesimpulan dari lapangan, maka penyajian data bisa dilakukan dalam bentuk uraian singkat, bagan, serta hubungan antar teori.

Tahap ketiga yaitu penarikan kesimpulan. tahap ini dimaksudkan untuk mencari makna data yang dikumpulkan dengan mencari hubungan, persamaan, atau perbedaan. Penarikan kesimpulan dilakukan dengan jalan membandingkan kesesuaian pernyataan dari subyek penelitian dengan makna yang terkandung dengan konsepkonsep dasar dalam penelitian tersebut. Kesimpulan dalam penelitian kualitatif dapat berupa deskripsi atau gambaran suatu objek yang sehingga setelah diteliti menjadi jelas.

\section{HASIL DAN PEMBAHASAN}

Berdasarkan observasi yang peneliti lakukan, diperoleh data-data tentang perencanaan, pelaksanaan, dan penilaian dalam pembelajaran. Data tersebut diperoleh dengan mendokumentasikan dokumen perangkat yang dibuat disekolah mulai perangkat perencanaan, perangkat pelaksanaan, dan perangkat penilaian. Selain melakukan observasi, penulis melakukan wawancara terhadap Kepala sekolah dan guru kelas IV. Wawancara ini dilakukan untuk memperoleh informasi lebih dalam lagi mengenai pelaksanaan K13 di kelas IV SD Inpres 135 Hasik Jaya. Hasil dari wawancara tersebut untuk memperkuat data yang diperoleh dari hasil observasi.

Reduksi data dilakukan terhadapat data yang diperoleh dengan memilih dan memfokuskan kepada hal-hal yang pokok dengan pertimbangan data yang direduksi akan memberikan gambaran yang lebih jelas. Dalam penelitian ini, dimana bertujuan untuk mengetahui bagaimana pelaksanaan K13 dalam proses pembelajaran di kelas IV SD Inpres 135 Hasik Jaya Kabupaten Sorong 
Selatan, setelah peneliti memasuki tempat penelitian, maka dalam mereduksi data, peneliti akan memfokuskan pada guru kelas IV. Selanjutnya adalah Penyajian data. Melalui tahap ini, data terorganisasikan, tersusun dalam pola hubungan, sehingga akan mudah dipahami. Data disajikan dalam teks yang bersifat naratif dan disusun ke dalam urutan sehingga strukturnya dapat dipahami. Penarikan kesimpulan dilakukan setelah data direduksi, kemudian disajikan.

Dalam menganalisis datamenggunakan pendekatan induktif, yaitu cara berpikir berangkat dari fakta-fakta yang khusus, peristiwa yang bersifat kongkrit, kemudian ditarik generalisasinya yang bersifat umum dan berpikir tolak pada penguatan yang umum itu kita hendak menilai sesuatu kejadian yang khusus.

\section{Analisis Data Pelaksanaan K13}

Hasil observasi dibagi dalam tiga tahap, tahap perencanaan, pelaksanaan, dan penilaian. Berdasarkan hasil observasi perencanaan tentang komponen pemahaman guru tentang buku pedoman guru dan buku pedoman siswa yaitu guru sudah memahami kelengkapan buku dan memahami hubungan fungsional buku pedoman guru dan buku teks pelajaran dalam proses pembelajaran dengan baik. Guru juga sudah memahami kelengkapan buku teks pelajaran dan hubungan aktifitas pembelajaran dengan sumber dan media pembelajaran.

Tahap perencanaan di SD Inpres 135 Hasik Jaya sudah sesuai dengan kaidah dalam K13. Karena dalam pembuatan RPP sudah memenuhi komponen-komponen K13, yaitu identitas tema/subtema, perumusan indikator, perumusan tujuan pembelajaran, pemilihan materi ajar, pemilihan sumber belajar, pemilihan media belajar, model pembelajaran, skenario pembelajaran, dan penilaian.
Hal ini menunjukkan bahwa guru-guru di SD Inpres 135 Hasik Jaya selalu melakukan langkah-langkah perencanaan dalam melakukan pembelajaran agar tidak kebingungan dalam proses pembelajaran di kelas. RPP tematik pada K13 merupakan hasil Kelompok Kerja Guru (KKG) semua sekolah yang melaksanakan kurikulum 2013. Pada KKG semua guru yang melaksanakan K13 berkumpul lalu dikelompokkan per kelas yang dalam kelompok tersebut mempunyai pembagian tugas untuk setiap guru. Masing-masing guru membuat RPP Tematik pada tema yang sudah ditentukan. Hasilnya dikumpulkan di kelompok lalu hasil dari beberapa kelompok tersebut dikumpulkan dan digandakan serta dibagikan kepada masing-masing sekolah yang melaksanakan K13.

Selain RPP disusun secara kolektif pada saat KKG, hambatan lain yang dialami guru adalah dalam mempersiapkan media pembelajaran di kelas. Guru mengalami kesulitan dalam memepersiapkan media pembelajaran yang digunakan setiap hari. banyaknya perencanaan yang kurang sesuai dengan tema karena kurang mempersiapkannya guru dalam proses perencanaan untuk mengajar di kelas, sehingga antara rencana dengan tema kurang sesuai dengan yang diajarkan. Hampir semua metode sering digunakan di kelas IV sesuai dengan tema yang cocok antara lain ceramah, tanya jawab, demontrasi, diskusi kelompok. Dengan adanya berbagai metode yg digunakan dalam pembelajaran, pembelajaran diharapkan tidak monoton dan siswa lebih aktif dalam mengikuti pembelajaran di kelas.

Berdasarkan hal diatas, penggunaan berbagai metode pembelajaran di K13 memang dibutuhkan, namun dalam menggunakan metode pembelajaran harus 
disesuaikan dengan tema.

Pelaksanaan Model pembelajaran K13 merupakan inti dari aktifitas pembelajaran yang dalam pelakasanaannya disesuaikan dengan rambu-rambu yang telah disusun RPP. Tahap ini merupakan tahap penerapan yang sudah dibuat oleh guru dalam perencanaan. Dalam pembelajaran K13 ada tiga kegiatan pembelajaran yaitu kegiatan pendahuluan, kegiatan inti, dan kegiatan penutup.

Hasil observasi yang di lakukan di SD Inpres 135 Hasik Jaya ditemukan bahwa guru belum melaksanakan pembelajaran tematik K13 dengan baik. Kegiatan pendahuluan yang dilakukan guru belum mengaitkan materi pembelajaran dengan pengalaman peserta didik, guru tidak melaksanakan kegiatan pendahuluan sesuai dengan aturan pada pelaksanaan K13. Guru SD Inpres 135 Hasik Jaya langsung masuk ke tema dengan tidak mendemonstrasikan sesuatu yang terkait dengan tema dan guru tidak mengecek kesiapan peserta didik untuk pengikuti pelajaran.

Pengelolaan pembahasan materi pelajaran masih mengalami hambatan yaitu guru terlihat kebingungan dalam mengkorelasikan antara mata pelajaran satu dengan mata pelajaran yang lain dalam satu tema, selain itu guru sering kehabisan bahan materi saat memberikan bahan ajar di kelas, serta kurang mempersipkan media pembelajaran yang akan digunakan. Kemampuan guru dalam menyesuaikan materi dengan tujuan pemberlajran belum terlihat, hal itu dikarenakan pada guru SD Inpres 135 Hasik Jaya kurang menguasai materi. Selain itu, guru terlihat kesulitan dalam mengaitkan materi dengan pengetahuan lain yang relevan dan mengaitkan materi dengan kehidupan nyata.

Pada kegiatan penutup, guru sudah melakukan refleksi dengan melibatkan peserta didik, pengumpulan hasil kerja sebagai bahan portofolio dan sudah melaksanakan tindak lanjut dengan memberikan arahan kegiatan berikutnya. Kendala dalam pelaksanaan pembelajaran K13 adalah kurangnya media pembelajaran untuk peserta didik, karena guru terlalu sering menggunakan satu macam metode yaitu ceramah. Terkait pengelolaan ruangan dalam melaksanakan kegiatan belajar mengajar juga berpengaruh terhadap keberhasilan pembelajaran terutama pada pembelajaran K13. Pengelolaan ruangan yang dilakukan oleh guru disesuaikan dengan kebutuhan pada pembelajaran di hari itu, misalnya tempat duduk berkelompok, klasikal, dan di luar kelas.

Hasil wawancara dengan guru kelas IV SD Inpres Hasik Jaya yang bernama Ibu Sudarmi, S.Pd. menunjukkan Guru selalu menggunakan buku guru dan buku siswa dalam pembelajaran tematik K13. Dalam menentukan materi untuk diajarkan dalam pelaksanaan pembelajaran sebelum melakukan pembelajaran, guru membaca RPP yang akan dilalui bersama peserta didik. Jenis penilaian apa yang digunakan guru dalam pembelajaran kurikulum 2013 menggunakan jenis penilaian penguasaan pengetahuan dan penilaian sikap peserta didik. Guru tidak menggunakan penilaian autentik, untuk penilaian pada tematik K13 membutuhkan keterampilan khusus dari guru, karena pembelajaran tematik tidak ada pembeda mata pelajaran, tetapi pada penilaian dilakukan per mata pelajaran.

Hasil wawancara dengan Kepala SD Inpres Hasik Jaya yaitu Ibu Kristina Sampe, S.Pd., diperoleh bahwa pelaksanaan pembelajaran tematik K13 memiliki konsep yang sangat bagus menekankan pada keterampilan, untuk aspek pengetahuan 
untuk sekolah yang maju masih sangat minim, namun untuk pembentukan sikap sudah cukup bagus. Guru harus merencanakan dan melaksanakan pembelajaran agar dapat mengakomodasi siswa yang memiliki perbedaan tingkat kecerdasan, pengalaman, dan ketertarikan terhadap suatu topik. Guru juga harus mmbaca buku pedoman. Untuk persiapan pembelajaran, dibuat secara kolektif disusun berdasarkan tema dan sub tema pada hari itu juga.

\section{KESIMPULAN}

Hasil penelitian menunjukkan bahwa guru di SD Inpres 135 Hasik Jaya sudah paham mengenai pembelajaran tematik K13. Bentuk pelaksanaan pembelajaran tematik di SD Inpres 135 Hasik Jaya dibagi dalam tiga yaitu perencanaan, pelaksanaan pembelajaran dan penilaian. Ketiga hal ini merupakan bagian dari langkah-langkah pelaksanaan pembelajaran tematik K13. Setiap sekolah yang melaksanakan K13 menggunakan perencanaan yang sama yang dibuat dalam $\mathrm{KKG}$, tetapi dalam pelaksanaannya tetap menyesuaikan pengelolaan masing-masing guru di sekolah.

Dalam pembuatan perencanaan, dari hasil observasi yang dilakukan, RPP dibuat oleh guru sudah sesuai dengan komponenkomponen RPP K13. Dalam tahap pelaksanaan pembelajaran guru sudah melakukan pembelajaran sesuai dengan RPP yang dibuatnya. Kendala yang guru alami adalah kekurangan media dalam pembelajaran. Dalam tahap penilaian guru mengalami kebingungan dalam melaksanakan proses penilaian, karena pada saat pembelajaran dilaksanakan dengan pendekatan tematik, namun dalam tahap penilaian guru harus melakukan peniliaan per mata pelajaran.

\section{DAFTAR RUJUKAN}

Abdul Majid. (2014). Strategi Pembelajaran. Bandung: PT Remaja Rosdakarya.

Ahmad, Susanto. (2015). Teori Belajar Dan Pembelajaran Disekolah Dasar. Jakarta: Prenada Media

Arikunto, Suharsimi. (2010). Prosedur Penelitian Suatu pendekatan Praktek. Jakarta: Rineka Cipta.

Artapati, L. W., \& Budiningsih, C. A. (2017). Pelaksanaan pembelajaran Kurikulum 2013 di SD Negeri Serayu Yogyakarta. Jurnal Inovasi Teknologi Pendidikan, 4(2), 185-200.

Creswell, John W. (2010). Research Design : Pendekatan Kualitatif, Kuantitatif, Dan Mixed.Yogyakarta: Pustaka Pelajar.

Ermalinda, Paizaluddin. (2014). Penelitian Tindakan Kelas: (Classroom Action Research) Panduan Teoritis dan Praktis. Bandung: Alfabeta.

Hurit, A. A., \& Harmawati, D. (2019). Analisis Kesiapan Guru dalam Mengimplementasikan Kurikulum 2013 di SD Inpres Gudang Arang Merauke. Musamus Journal of Primary Education, 116-123.

Isjoni (2009). Pembelajaran Kooperatif. Yogyakarta : Pustaka Belajar.

Jessica, A. R. A., Harmianto, S., \& Mareza, L. (2020). Penerapan Literasi Digital dalam Pembelajaran Kurikulum 2013 Berbasis E-Learning Tema 8 Bumiku Kelas VI SD Negeri 2 Purbalingga Lor. Jurnal Papeda: Jurnal Publikasi Pendidikan Dasar, 2(2), 139-146.

Komalasari, Kokom (2013). Pembelajaran Konstektual. Bandung: Refika Adiatama.

Mulyasa. (2014). Pengembangan dan Implementasi Kurikulum 2013. Bandung: Remaja Rosdakarya.

Muzamiroh, Mida Latifatul (2013). Kupas Tuntas Kurikulum 2013. Surabaya: Kata Pena.

Yuniasih, N., Ladamay, I., \& Wahyuningtyas, D. T. (2014). Analisis pembelajaran tematik pada kurikulum 2013 di SDN Tanjungrejo 1 Malang. Mimbar Sekolah Dasar, 1(2), 
148-152.

Nuryanis, N. (2017). ANALISIS PELAKSANAAN KURIKULUM 2013 DI SD NEGERI 11 KOTA LANGSA. Jurnal Inovasi Sekolah Dasar, 4(2).

Pramasanti, R., Bramasta, D., \& Anggoro, S. (2020). Implementasi pendidikan karakter tanggung jawab dan kerja sama dalam pembelajaran tematik kurikulum 2013 di sd negeri 2 berkoh. Jurnal Papeda: Jurnal Publikasi Pendidikan Dasar, 2(1), 4348.

Sarwono. S.W. (2011). Psikologi Remaja. Jakarta: PT Raja Grafindo Persada.

Shobirin, Ma'as. (2016). Konsep dan implementasi Kurikulm 2013 di Sekolah Dasar. Yogyakarta: Deepublish.

Sugiyono. (2018). Metode Penelitian Kuantitatif, Kualitatif, Dan $R \& D$.
Bandung: Alfabeta.

Sukmadinata. (2010). Metode Penenelitian Pendidikan. Bandung: PT Remaja Rosdakarya.

Sumantri, Mohamad Syarif. (2015). Strategi Pembelajaran: Teoro dan Praktik di Tingkat Pendidikan Dasar. Jakarta: PT Raja Grafindo Persada.

Surya, Mohamad. (2014). Psikologi Guru Konsep Dan Aplikasi. Bandung: Alfabeta.

Trianto. (2011). Model Pembelajaran Terpadu Konsep, Strategi Dan Implementasinya. Dalam Kurikulum Tingkat Satuan Pendidikan (KTSP). Jakarta: Bumi Aksara.

Upayanto, Imam Dwi. (2017). Pelaksanaan Proses Pembelajaran Kurikulum 2013 SD Negeri 4 Krandegan. Jurnal Pendidikan Guru Sekolah Dasar.

Yin, Robert K. (2014). Studi Kasus Desain \& Metode. Jakarta: Rajawali Pers. 